\title{
The Effect Of Internal Control On The Operating Activities Of Small Restaurants
}

Linval Frazer, College at Old Westbury, State University of New York, USA

\begin{abstract}
Researchers have found that more than 67\% of restaurants fail within the first 3 years of their operation. These findings underscore the restaurant industry's current crisis of profitability and survivability. The industry's average profit is generally small, ranging from 3\% to $7 \%$. Despite these problems, researchers have not examined the effect of internal control on the operating activities of small restaurants. Internal control is defined in this study as all the policies and procedures management uses to ensure the reliability of financial reporting, compliance with laws and regulations, and the effectiveness and efficiency of operations. The purpose of this study was to determine restaurant managers' perceptions of the internal control systems and (a) the protection of assets, (b) the segregation of duties, and (c) the verification of transactions. Two hundred and seventy restaurants were selected through random sampling, and multiple regression and exploratory data analysis, including descriptive statistics, were used to analyze the data. The multiple regression analyses indicated statistically significant relationships linking perceptions of internal control systems in restaurants with each of the 3 predictors; protection of assets, segregation of duties and verification of transactions. The results indicated that majority of the study group perceived restaurants' internal control system to be inadequate compared to the Committee of Sponsoring Organization Treadway Commission (COSO) internal control integrated framework. The results of this research have potential for social change as they may increase government compliance, and improve financial reporting and best business practices of restaurants.
\end{abstract}

Keywords: Internal Controls; Restaurants Profitability; Restaurants Survivability; Restaurants Failure and COSO.

\section{INTRODUCTION TO THE STUDY}

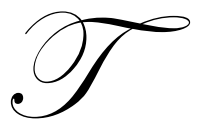

he restaurant industry is the second largest employer in the United States. It employs an estimated 13.1 million people, or 9\% of the workforce in the United States (National Restaurant Association [NRA], 2008)). More than 945,000 restaurants and food services locations with annual sales of more than $\$ 500$ billion exist in the United States (NRA, 2008). Restaurants generated more than $\$ 70$ billion in profits in 2008 (NRA, 2008). This total amounted to 47\% of what people in the United States spend on food annually (NRA, 2008). Typical restaurant food costs are about 30\% to 35\% of sales (Kotshevar \& Withrow, 2008; Brown, 2006). Payroll and employee benefits cost around $30 \%$ to $35 \%$ of sales (Kotshevar \& Withrow, 2008). The average industry profit is generally small, ranging from $3 \%$ to $7 \%$ (Kotschevar \& Withrow, 2008; NRA, 2008).

Few food service operations operate successfully if their combined costs of goods sold and labor costs are above $65 \%$, with the most common division being $35 \%$ food and beverage and $30 \%$ labor (Kotscevar \& Withrow, 2008). Operations with higher costs that operate well are usually subsidized in some way. According to Kotschevar and Withrow (2008), this 65\% figure is not universal. If there is proper internal control, the combined cost could total $75 \%$ and still leave a profit (Kotschevar \& Withrow, 2008; Brown, 2006).

Although the restaurant industry is important to the U.S. economy, a substantial number of restaurants fail in the first 3 years (English, 1996; Parsa, Self, Njite, \& King, 2005). Restaurant failures have been attributed to economic and social factors, competition and legal restrictions, and even government intervention, but most restaurant failures can be attributed to inadequate planning and improper internal control (Lee, 2006). Parsa et al. 
(2005) found that failure rates are notably higher for small, independent operations than for relatively large franchised restaurants. Parsa et al. (2005) also found that no restaurant had closed because of external forces. In contrast to earlier studies (English, 1996), Parsa et al. (2005) concluded that if restaurants are properly managed, external factors may not automatically lead to failure.

Boyle and Desai (1991) found that the majority of businesses fail because of internal factors affected by management's actions and disciplines. Boyle and Desai (1991) also found a negative correlation between the duration a firm is in business and its likelihood of failure; that is, if firms survive long enough, it is reasonable to expect that they have resolved their internal control issues. Doyle, Ge, and McVay (2005) supported Boyle and Desai's findings. Doyle et al. (2005) attributed the accounting scandals in 2001, to material weaknesses in internal control and the need for regulation. Doyle et al. (2005) also found that material weaknesses were more likely to occur in firms that are smaller, weaker, and younger. These findings have contributed to the call for more research on the factors associated with restaurants' survival (Parsa et al., 2005).

Previous studies on internal control bearings have focused on financial statements and their impact on the operation of firms (Curtis \& Borthick, 1999; Janvrin, 2003; Kiger \& Rose, 2004; Samson, Flesher, \& Previs, 2006). Other studies have focused on the documentation of internal control structures and the significant monetary effect of weak controls on the firm's value (Dow, Shea, \& Waldrup, 2009). The focus of this study is on internal control procedures in restaurants, on financial statements as well as the operation of restaurants through the use of the Committee of Sponsoring Organizations' ([COSO], 1992) internal control integrated framework to determine the extent to which best business practices lead to survivability. Operating activities are defined in this study as the sales and the expense activities that enter into the determination of operating income (Needles, Powers, \& Crosson, 2005). Operating profit is defined as the return from standard operations, excluding the impact of extraordinary items and other comprehensive income such as investments and financing (Garrison \& Noreen, 2009). The operating profit reveals the extent of a company's ability to earn profit from standard operation (S-VC-FC > 0) (Whittington \& Delaney, 2009; Garrison \& Noreen, 2009; Needles, Powers, \& Crosson, 2005)

\section{LITERATURE REVIEW \& HYPOTHESES}

The literature review includes a description of the COSO (1992) framework and the five components that are pertinent to best businesses practices. The rational choice theory (Becker, 1996; Cornish \& Clark, 1986; Rubin, 1978) and communication theory (Altman \& Taylor, 1987; Capella, 1985; Street \& Giles, 1982; Weick, 1979) in organizations are subsequently discussed. A focused discussion of the reasons restaurants fail follows.

\section{INTERNAL CONTROL INTEGRATED THEORETICAL FRAMEWORK}

According to the COSO (1992) internal control integrated framework, internal control encompasses the policies, rules, and procedures enacted by management to provide reasonable assurance that financial reporting is reliable, the operations are effective and efficient, and the activities comply with applicable laws and regulations. The AICPA (1972) identified two types of internal controls to help principals make decisions, namely by confirming or correcting agents' faithful performance of their duties and by providing information for future expectation. These financial controls are related to the reliability of financial information, and the administrative controls are related to the actions of agents and employees (Marchetti, 2005).

The corporate scandals of the 1980s saw many people lose their jobs (Marchetti, 2005). COSO was formed in 1985 to identify the various factors that can lead to fraudulent financial reporting and to develop recommendations to address these issues (Kieso, Weygandt, \& Warfield, 2005). In 1987, COSO published its findings of the gross corporate irregularities of the 1980s. The report indicated that fraud occurred because of improper internal control that included not only financial statement controls but also certain environmental, institutional, or individual forces and opportunities ([COSO], 1987).

As part of COSO's work in identifying the factors that contributed to corporate fraud, the members also designed a model for corporations to use to address the lack of proper internal controls in corporate organizations (Jackson, 2006). In 1992, COSO established the internal controls integrated framework for developing an effective 
internal control system. This framework provides direction to any business that wishes to establish an effective internal control system ([COSO], 1992). This now recognized framework consists of five interrelated components: control environment, risk assessment, control activities, information and communication, and monitoring ([COSO], 1992).

These five major components of the COSO (1992) internal control integrated theoretical framework are part of a holistic framework needed to strengthen efficiency within the management of any organization. Throughout this holistic framework, a variety of activities and steps are taken to ensure that the organizations do not provide opportunities for the manifestation of fraudulent behaviors by employees ([CSOS], 1992). The framework created based on these components is constantly assessed for clarity so that the implemented internal control functions throughout the lifespan of the organization ([COSO], 1992). The five components of internal control also work harmoniously to detect, prevent, or correct errors or misstatements in the overall operations of the business ([COSO], 1992). For the process of internal control to be seen as viable, all of the financial statements generated from all business activities must be authentic and noteworthy in accounting terms (Quall, 2004).

\section{CONTROL ENVIRONMENT}

According to COSO (1992), the control environment sets the tone for an organization (Pickett \& Pickett, 2005) by influencing the control consciousness of its people. It is the foundation for all of the other components of internal control because it provides discipline, structure (Nearon, 2005), integrity, ethical values, employee competence, management's philosophy and operating style, and the leadership provided by senior management and the board of directors (Quall, 2004).

\section{RISK ASSESSMENT}

According to COSO (1992), every organization, be it private or public, large or small, faces risks from external and internal sources that must be assessed. A precondition to risk assessment is the establishment of objectives that are linked at different levels and are internally consistent ([COSO], 1992). Risk assessment is the identification and analysis of risks relevant to the achievement of objectives ([COSO], 1992). This assessment determines how the risks should be managed ([COSO], 1992). Because economic, industry, regulatory, and operating conditions will continue to change, mechanisms are needed to identify and deal with the special risks associated with change.

\section{CONTROL ACTIVITIES}

Control activities are the policies and procedures that ensure how management directives are executed (Whittington \& Delaney, 2009). Control Activities include such activities as approvals, authorizations, verifications, reconciliations, reviews of operating performance, the safeguarding of assets, and the segregation of duties (Quall, 2004). These actions dissuade fraud or theft activities that could eventually lead to losses.

\section{INFORMATION AND COMMUNICATION}

Pertinent information must be identified, captured, and communicated in forms and timeframes that enable people to carry out their responsibilities. Information systems produce reports of operational, financial, and compliance-related information that make it possible to run and control the business (COSO, 1992). Information systems deal not only with internally generated data but also information about external events, activities, and conditions necessary to informed business decision making and external reporting (COSO, 1992). Effective communication also must occur in a broader sense by flowing down, across, and up the levels of the organization (COSO, 1992). All personnel must receive a clear message from top management that control responsibilities must be taken seriously (Quall, 2004). Employees in an organization must understand their own role in the internal control system, as well as how individual activities relate to the work of others (Pickett \& Pickett, 2005). Employees must have a means of communicating significant information upward (Jackson, 2006). Effective communication also must exist with external parties, such as customers, suppliers, regulators, and shareholders (COSO, 1992). 


\section{MONITORING}

Monitoring is a process that assesses the quality of the internal control system's performance over time through ongoing monitoring activities, separate evaluations, or a combination of the two (COSO, 1992). Ongoing monitoring occurs in the course of operations. It includes regular management and supervisory activities as well as other actions that personnel undertake while performing their duties (Jackson, 2006). The scope and frequency of separate evaluations depend primarily on an assessment of risks and the effectiveness of ongoing monitoring procedures (COSO, 1992). Internal control deficiencies should be reported upward, with serious matters reported to top management and the board of directors (COSO, 1992; Jackson, 2006).

\section{RATIONAL CHOICE THEORY IN ORGANIZATIONS}

According to Daft (2007), managers should try to use systematic procedures to make decisions. When managers have a deep understanding of the rational decision-making process, they can make better decisions, even if they lack some clear information (Daft, 2007). Daft explained that the point of the rational approach is that managers should try to use systematic procedures to arrive at good decisions. When managers understand the issues facing them, they generally use rational procedures to make decisions.

Simmon (1947) argued that organizations can never be entirely rational because their members have limited information-processing abilities. Simmon (1947) asserted that people (a) usually have to act on the basis of incomplete information about possible courses of action and their consequences, (b) are able to explore only a limited number of alternatives relating to any given decision, and (c) are unable to attach accurate values to the outcomes. Simmon (1947) suggested that, at best, people can achieve only limited forms of rationality. In contrast, Simmon (1947) also concluded that individuals and organizations settle for a "bounded rationality" of "good enough" decisions based on convention as well as limited search and information.

Cook (1980) and Simmon (1947) argued that rational choice theory has been used not only to describe how crime depends on the interaction between offenders and victims in organizations but also to join, leave, perform, and determine how much effort to exert in any given circumstance in an organization. These decisions are constrained by imperfect (bounded) rationality, so the individuals in organizations are aware of both constraints and opportunities in their organizational environment (Simmon, 1947). For instance, individuals in organizations use this information in their decisions to come to work, call in sick, and so on. According to Cook (1980) and Simmon (1947), these rationales can be readily adapted to explain forms of misbehavior because individuals are aware of the opportunities as well as the consequences of engaging in misconduct. Cook (1980) and Simmon (1947) also concluded that if individuals decide to engage in misconduct, they are attracted to crime targets that provide a high payoff with little effort and low risks of apprehension.

Victims, on the other hand, in their effort to negate victimization, take a variety of precautions to reduce the alternatives of crime. Victims try to make it more difficult for offenders to complete their crimes successfully, they try to increase the likelihood that offenders will be detected and apprehended, and they try to reduce their loss if they are victimized (Liska \& Messner, 1999). Internal controls in restaurants can increase the likelihood of offenders being apprehended and reduce lost through fraudulent activities.

Crime prevention measures have two linked emphases: reducing the physical opportunities for offending and increasing the risk of an offender being caught (Downes \& Rock, 2003). The first embraces such examples as the replacement of vulnerable cash register in a restaurant with modern Point of Sale Systems (POS) systems (Downes \& Rock, 2003). The second preventative approach builds on the assumption that there is good deal of unrealized potential for making use of the surveillance role of employees who come into regular and frequent contact with the public in a semiofficial capacity (Downes \& Rock, 2003). These crime prevention measures translate the physical environment into terrain patrolled, watched, and guarded by official and unofficial custodians. Proper internal controls in small or large organizations can make a considerable impact on specific crime (Downes \& Rock, 2003). For example, a restaurant with the least areas of supervision attracts the most damage. 
Maingot (1994) posited that individuals use the rational choice theory when they are contemplating a deviant act and must weigh their fear of sanctions and disapproval with the potential for gain and gratification. The outcome of a decision toward a deviant act is changed by the weight placed on the fear of being caught or the benefits gained when the decision is being made. Daft (2007) argued that the rational approach to individual decision making stresses the need for systematic analysis of a problem followed by choice and implementation in a logical, step-by-step sequence. Although the rational model is an ideal not fully achievable in the real world of uncertainty, complexity, and rapid change, the model does help managers to think about decisions more clearly and rationally.

\section{METHODOLOGY}

This study was designed to investigate restaurant managers' perception of the internal control systems in small restaurants operating in Nassau County in New York State, and if a significant relationship exists between the dependent variable, restaurant managers' perception of internal control system, and the independent variables, protection of assets, segregation of duties, and verification of transactions. The survey method was used to gather data from respondents that own or operate restaurants in Nassau County of New York State. The collected data were analyzed statistically to establish the findings.

\section{SAMPLING PROCEDURE}

The participants were selected by random sampling. The ultimate goal of the research is to arrive at findings that have general applicability (McTavish \& Loether, 1999). The participants were chosen from a list of the small restaurants in Nassau County in New York State that have been in operation for at least the last 3 years. The criteria to participate in this study are that (a) the participants must be the managers of small restaurants operating in Nassau County in New York State, (b) the participants must have at least 10 employees, and (c) the participants must have been in business for at least the last 3 years.

According to the National Restaurant Association ([NRA], 2009), there are 1,173 restaurants in Nassau County, including small and large restaurants. A random sample of 270 restaurants was drawn as a subset of the total population of all the small restaurants listed on the New York State Restaurant Association's database of small restaurants in Nassau County in New York State that have been in business for at least 3 years. All the names of the small restaurants operating for at least 3 years in Nassau County were assigned a numeric value and were entered in an Excel formula function that randomly selected 270 restaurants as the sample frame from the target population. If a restaurant was selected that did not meet the criteria for selection, I discarded that selection and make another selection.

According to Fowler 2002, there are three attributes that must be considered in connection with a sampling frame: (a) comprehensiveness, (b) probability of selection, and (c) efficiency. All the small restaurants in Nassau County in New York State were entered in the Excel formula function and a random selection of 270 restaurants was made from the restaurants ensuring that Fowler's criteria are met.

\section{DATA COLLECTION}

The sample comprised of 270 restaurants operating in Nassau County in New York State that were selected through random sampling. I telephoned the selected restaurants and introduce the study to the managers. I then scheduled an appointment with the manager of each restaurant over the course of 3 weeks. Restaurant managers were given the option of doing the survey by mail, telephone or by face to face interview. The survey was then administered to the manager of each restaurant to fill out. The survey was conducted over 3 weeks. I made follow-up telephone calls to the restaurant managers weekly over the 3-week period. Internet or web survey was considered but rejected because such survey of the restaurant population can be subjected to bias if the respondents are restricted to restaurant owners who use only the Internet, which could result in low response rates. There also is no systematic way to sample the general population using a web survey because there is difficulty obtaining a sample frame in which every individual in the target population has a known chance of being selected for participation (Dillman, 2000). In addition, extremes in variation of users and equipment capabilities can affect sampling (Bradley, 1999). 


\section{RESEARCH QUESTIONS}

Following are the research questions that guided this study:

1. What are the restaurant manager's perceptions of the internal control systems in small restaurants operating in Nassau County in New York State?

2. What is the nature of the relationship between the segregation of duties and restaurant managers' perception of the internal control systems in small restaurants operating in Nassau County in New York State?

3. What is the nature of the relationship between the protection of assets and restaurant managers' perception of the internal control systems in small restaurants operating in Nassau County in New York State?

4. What is the nature of the relationship between the verification of transactions and restaurant managers' perception of the internal control systems in small restaurant operating in Nassau County in New York State?

5. Are internal control systems in consistent with COSO standards present in small restaurants operating in Nassau County in New York State?

The first research question was addressed descriptively through exploratory data analysis using descriptive statistics and charts. The second through fourth research questions were assessed by testing the hypothesis listed in the section below. The fifth research question was addressed descriptively by comparing the responses given by the restaurant owners regarding internal control systems to the COSO standards.

\section{HYPOTHESES}

The following hypotheses were tested in this study:

$H_{0} 1$ : There is not a significant relationship between the restaurant managers' perception of the segregation of duties, and their perception of the internal control systems.

$H_{1} 1$ : There is a direct negative relationship between the restaurant managers' perception of the segregation of duties, and their perception of the internal control systems.

$H_{0}$ 2: There is not a significant relationship between restaurant managers' perception of protection of assets, and their perception of the internal control systems.

$H_{1}$ 2: There is a direct positive relationship between restaurant managers' perception of protection of assets and their perception of the internal control systems

$H_{0} 3$ : There is not a significant relationship between restaurant managers' perception of verification of transactions and their perception of the internal control systems

$H_{1} 3$ : There is a direct positive relationship between restaurant managers' perception of verification of transactions and their perception of the internal control systems

$H_{0} 4$ : The level of internal control is not adequate by obtaining a mean score of 4 or 5 in the survey questionnaire.

$H_{1} 4$ : The level of internal control is adequate by obtaining a mean score of 4 or 5 in the survey questionnaire.

\section{DATA ANALYSIS}

The response data from the survey was entered into SPSS version 16.0 software for statistical analysis. A linear regression analysis was used to analyze the data. Singleton and Straits (2005) commented that regression analysis is the effect of one interval or ratio variable on another. The four variables that were analyzed are one dependent variable and three independent variables. The dependent variable was internal control in restaurants (Y1). The three independent variables are (a) protection of assets (X1), (b) segregation of duties (X2), and (c) verification of transactions (X3). A 5-point Likert scale was used to integrate the theoretical framework examining the dependent and independent variables. Each question on the Likert scale had five possible answers, with possible scores ranging from 5 (best possible internal control) to 1 (lowest possible internal control). Total scores as defined by the maximum points on the instrument were obtained for each set of independent variable questions. The average of the total scores was used as a predictive construct validity measurement. Low scores indicated a lack of internal control, and high scores indicated adequate internal controls (Kistler, 2008). 
The mean score was determined by averaging all scores for the dependent variable and the three independent variables. The mean score for each variable was used to determine whether internal control was adequate or inadequate among the sample of restaurants operating in Nassau County in New York State. A reading of 4 (Likely) or 5 (Very Likely) on the Likert scale indicated that for-profit standard has been achieved, which is consistent with the COSO (1992) framework.

Factor analysis was conducted to assess how well each of the questions measured the independent variables. According to Rea and Parker (1992), "the main applications of factor analytic techniques are: (1) to reduce the number of variables and (2) to detect structure in the relationships between variables, that is to classify variables. Therefore, factor analysis is applied as a data reduction or structure detection method" (StatSoft, 2010, para. 1). Combining two (or more) correlated variables into one factor, illustrates the basic idea of factor analysis, or of principal components analysis to be precise (Statsoft, 2010, para. 8). Principle components analysis (PCA) is a common technique for finding patterns in data of high dimension (Leedy \& Ormund, 2005). Thus, for each of the independent variables, the items on the survey were assessed with PCA to determine if they are measuring the same factor or component.

The following logistic regression module summarizes the variables and design for the research:

$$
\text { INTCTR }=\beta 0+\beta 1 \text { PRASSET }+\beta 2 \text { SEGDTY }+\beta 3 \text { VERTRN }+\varepsilon
$$

Internal control in restaurants is the dependent variable or the predicted value. The dependent variable depends on the regression of the independent variables and their slopes. The slopes of the independent variables will determine whether the dependent variable's value will increase or decrease in the same or in the opposite direction.

The error term $(\varepsilon)$ describes the values of all other variables other than the independent variables that would affect the dependent variable. Beta zero $(\beta 0)$ is the slope intercept of the regression line or the value when all the independent variables are zero. INTCTR $=4$ to 5 for a restaurant that has internal control procedures analogous with COSO standard, and 1 to 3 is below COSO standard. ASSET $=4$ to 5 for a restaurant that has adequate procedures to protect asset consistent with COSO standards and 1 to 3 is below COSO standard. SEGDTY $=5$ for a restaurant that has adequate procedures to segregate duties consistent with COSO standards, 1 to 3 is below COSO standard. VERTRN $=5$ for a restaurant that has adequate procedures to verify transactions consistent with COSO standards, and 1 to 3 is below COSO standard.

\section{EMPIRICAL RESULTS}

Research question 1 was assessed using exploratory data analysis, including descriptive statistics. The mean score for the dependent variable, internal control, was 2.97 (s.d. $=1.17$, Table 1). The mean score for the independent variable, segregation of duties, was 2.89 (s.d. $=1.02$, Table 1), while the mean score for the independent variable, protection of assets, was 3.31 (s.d. $=1.12$, Table 1). The mean score for the independent variable, verification of transactions, was $3.10($ s.d. $=1.26$, Table 1$)$. These mean scores are near 3.0, which represents a neutral response. Since these means are all below 4.0, which represents the cut-off between adequate and inadequate control, it can be concluded that, on the average, small restaurants operating in Nassau County in New York State have internal control systems that are considered inadequate.

Table 1

Mean and standard deviation for the four study variables $(n=117)$

\begin{tabular}{lcc}
\hline & Mean & Std. Deviation \\
\hline Internal control & 2.97 & 1.17 \\
Segregation of duties & 2.89 & 1.02 \\
Protection of assets & 3.31 & 1.12 \\
Verification of transactions & 3.10 & 1.26 \\
\hline
\end{tabular}


For each variable, the restaurants' scores were divided into two groups, those with adequate control and those with inadequate control. Since a score of 4 (Likely) or 5 (Very Likely) on the Likert scale indicated that forprofit standard had been achieved, the restaurants with a mean score above 4.0 were considered to have adequate control. Thus, the restaurants with mean scores greater than or equal to 4.0 were categorized as adequate, while scores below 4.0 were considered inadequate. Table 2 displays the frequency of occurrences for the four variables, and each of the variables had a higher percentage of restaurants with inadequate control than adequate control. For internal control and verification of transactions, 77 (66\%) restaurants had inadequate control, while only 40 (34\%) were categorized as adequate. Of the restaurants overall, $92(79 \%)$ had inadequate segregation of duties, while only $25(21 \%)$ had adequate segregation of duties. Seventy-four $(63 \%)$ of the restaurants had inadequate protection of assets, while only $43(37 \%)$ had adequate segregation of duties.

To determine if the percents (also called proportions) shown in Table 2 are significantly different from 50 $\%$, a one-sample binomial test was conducted. A one sample binomial test is used to test whether the proportion of occurrences for a two-level categorical variable significantly differs from a hypothesized value (Creswell, 2003). For this study, I wanted to determine if the proportions were significantly different from 0.50 (50\%), which would mean that the percent of restaurants with inadequate control was equal to the percent of restaurants with adequate control. Since the $p$-values for all four variables are less than alpha of 0.05 (Table 3), the null hypotheses that the proportions are equal to 0.50 are rejected. Thus, the one-sample binomial test results were significant for all four variables, which indicate that the proportions were significantly different from $50 \%$. Thus, the percent of restaurants operating with inadequate internal control systems are significantly greater than $50 \%$. It can be concluded that the managers of small restaurants operating in Nassau County in New York State perceive the internal control, segregation of duties, protection of assets, and verification of transactions in their restaurants to be inadequate.

Table 2

Frequency of occurrence for restaurants with inadequate control and adequate control

\begin{tabular}{lccc}
\hline & Inadequate Control & Adequate Control & Total \\
\hline Internal Control & $77(66 \%)$ & $40(34 \%)$ & 117 \\
Segregation of Duties & $92(79 \%)$ & $25(21 \%)$ & 117 \\
Protection of Assets & $74(63 \%)$ & $43(37 \%)$ & 117 \\
Verification of Transactions & $77(66 \%)$ & $40(34 \%)$ & 117 \\
\hline
\end{tabular}

Research questions 2 through 4 were assessed with hypotheses 1 through 3, respectively. Hypotheses 1 through 3 were tested using a multiple regression analysis. The results of the regression analysis indicated that all three independent variables were significant predictors of the dependent variable, since the observed significance $(p$ $=0.000$, Tables 4 and 6 ) was less than alpha of 0.05 . The regression model was determined to be

$$
\text { INTCTR }=-0.218-0.121 * \text { SEGDTY }+0.676 * \text { PRASSET }+0.419 * \text { VERTRN }+\varepsilon
$$

where INTCTR represents internal control, PRASSET represents protection of assets, SEGDTY represents segregation of duties, VERTRN represents verification of transactions, and $\varepsilon$ represents the standard error of the estimate (Table 6). Research question 2 was addressed using hypotheses 1 . There is a negative relationship between segregation of duties and internal control as evidenced by the negative slope of -0.121 . This indicates that the dependent variable internal control will decrease by a factor of -0.121 for every value of segregation of duty that is computed. Research question 3 was addressed using hypotheses 2 . There is a positive relationship between protection of assets and internal control as evidenced by the positive slope of 0.676 . This indicates that the dependent variable internal control will increase by a factor of 0.676 for every value of protection of asset that is computed. Research question 4 was addressed using hypotheses 3. There is a positive relationship between verification of transactions and internal control as evidenced by the positive slope of 0.419 . This indicates that the dependent variable internal control will increase by a factor of 0.419 for every value of verification of transactions that is computed. 
Table 3

Coefficients for the Multiple Regression Analysis

\begin{tabular}{ll}
\hline Coefficient & \\
\hline $\mathrm{R}$ & .992 \\
$\mathrm{R}^{2}$ & .984 \\
Std. Error of the Estimate $(\varepsilon)$ & .15048 \\
\hline
\end{tabular}

Table 4

\begin{tabular}{lcccc}
\multicolumn{5}{c}{ Results of the Multiple Regression Analysis } \\
\hline \multicolumn{7}{c}{ INTERCEPT } & SEGDTY & PRASSET & VERTRN \\
\hline $\boldsymbol{b}(\boldsymbol{b})$ & -0.2182 & -0.121039 & 0.676689 & 0.419589 \\
$\boldsymbol{t}$ & 0.06387 & 0.052065 & 0.107938 & 0.078228 \\
$\boldsymbol{p}$ - value & -3.417 & -2.324758 & 6.269243 & 5.363649 \\
\hline
\end{tabular}

Furthermore, the correlation coefficient (R) was 0.992 (Table 3), which indicates that there is a very strong correlation between the independent variables and the dependent variable, internal control. In addition, the coefficient of determination $\left(R^{2}\right)$ was 0.984 (Table 3), which indicates that $98.4 \%$ of the variability in the internal control in small restaurants operating in Nassau County in New York State was accounted for by the independent variables, verification of transaction, protection of assets, and segregation of duties. It can be concluded that there is a positive relationship between the independent variables protection of assets and verification of transactions and the dependent variable internal control, and there is a negative relationship between the independent variable segregation of duties and the dependent variable internal control.

Research question 5 was addressed with hypothesis 4 . A one-sample t-test was used to test hypothesis 4 by comparing the mean score for internal control to the value of 4.0 to determine if it was significantly greater. The mean score was 2.97 (s.d. $=1.17$, Table 1 ) and the $t$-test had a $p$-value that was less than alpha of 0.05 " $p<.05$ ", therefore, the mean score for internal control was not significantly greater than four. In addition, as described above for research question one, the proportion of restaurants categorized with inadequate internal controls was significantly greater than $50 \%$. Therefore, the results of this study indicate that the mangers of small restaurants operated in Nassau County of New York State perceive the restaurants' internal control systems to be inadequate.

\section{CONCLUSION, LIMITATION, AND FUTURE STUDIES}

The results of this study support earlier findings that supported a relationship between internal controls and failure rate (English, 1996; Parsa, Self, Njite, \& King, 2005) and profitability (Lee, 2006). The implication of this research is that restaurants managers who have negative perceptions of internal controls systems may not consider the usefulness of internal control systems and its relationship to cost, profitability, and survivability. In contrast, restaurant managers who have positive perceptions of internal control systems may increase profit margin, lower costs, and increase the return on investment (Doyle et al., 2005; Eldridge \& Kealey, 2005; Franco et al., 2005)

The results support Doyle et al.'s (2006) findings in that material weaknesses in internal controls are more likely in organizations that are smaller, younger and financially weaker. Although the size, structure, and financial resources of the company affect its ability to establish internal control, the need for internal control is unique to each organization's particular operating environment. Krippel et al (2008) concluded from their study that the number of small hospitality companies declined while the number of franchise operations increased. This was attributed to restaurant managers being able to master various essential skills and closely scrutinize the details of the organization. No system of internal control is without any weaknesses (Brown, 200), but basic internal control procedures may enhance profitability and survivability of restaurants. 


\section{RECOMMENDATIONS FOR FUTURE RESEARCH}

The findings of this study offer several recommendations for future research. First, it would be interesting to see this study replicated on a larger scale, example, for the entire restaurant industry. This would include other restaurants operating in other states that have lower operating costs and lower prices. Would reduce business cost such as lower taxes, lower utility, and real estate or rent expense affect internal control systems in restaurants?

Second, this study could be replicated in other small businesses that are not restaurants. It would be helpful to determine if internal control is adequate in other small businesses because these findings could help other small businesses identify cost constraints and be better able to deal with high costs associated with internal control problems. Future research is warranted because small businesses managers need to understand how to design and implement internal control systems that are congruent with their operating environment. This understanding would help them to collectively and individually understand and share existing internal control measures to improve small businesses operations, survivability and profitability

Finally, it is recommended that this study be replicated with profitability ratios such as profit margin and or return on assets. This recommendation is proposed because financial ratios are the most common measure of how well a business is performing. Ratios express the mathematical relationship between one quantity and another. Profitability ratios may aid in measuring the success or failure of restaurants. Profitability is also linked to liquidity because earnings ultimately produce cash flow. Profitability management is a complex activity that includes, first, achieving a satisfactory gross margin and, second, maintaining acceptable levels of operating expenses. Achieving a satisfactory gross margin depends on setting appropriate prices for merchandise and services and purchasing merchandise at favorable prices and terms. Maintaining acceptable levels of operating expenses depends on controlling expenses and operating efficiently. Future research may focus on determining if there is a significant relationship between internal control systems and profitability of restaurants using profitability ratios

\section{CONCLUDING STATEMENT}

The findings of this study demonstrated evidence that internal control, grounded in rational choice theories, communication theories, and the COSO integrated theoretical framework, can have positive effects on small restaurants survivability and profitability. In an economy with seemingly endless economic instability leading to higher failure rates of small businesses, proper internal controls can aid in making small businesses more sustainable and profitable. While changes cannot be effected overnight or for that matter weeks, with meticulous approach to managing resources through adequate internal control measures and strong commitment to social change, small businesses can become more profitable and solvent over a period of time. While I understand that there are other external extenuating factors that affect small businesses in an economy, and inherent limitations in any system, nevertheless, internal control structures provide reasonable assurance that assets are safeguarded and that financial information is objective and reliable.

\section{AUTHOR INFORMATION}

Linval Frazer is an assistant professor of accounting at The College at Old Westbury State University, and an accounting and business professor at Berkeley College. His main research interests are auditing, internal controls and financial accounting. E-mail: frazerl@oldwestbury.edu

\section{REFERENCES}

1. Altman, I., \& Taylor, D. A. (1973). Social penetration: The development of interpersonal relationships. New York, NY: Holt, Rinehart \& Winston.

2. $\quad$ Allison, P. D. (1999). Multiple Regression. Thousand Oaks, CA: Pine Forge Press.

3. Alonzo, S. R. (2007). Owning and managing a restaurant ( $2^{\text {nd }}$ ed.). New York, NY: Kaplan.

4. American Institute of Certified Public Accountants. (1972). Statement on auditing procedure No. 48. New York, NY: Author. 
5. American Institute of Certified Public Accountants. (2006). Communicating internal control related matters identified in an audit (Statement on Auditing Standards No. 112). New York, NY: Author.

6. Ashbaugh, H., Collins, D., \& Kinney, W. (2006). The discovery \& reporting of internal control deficiencies prior to SOX-mandated audits. Journal of Accounting and Economics, 44(1-2), 166-192.

7. Becker, G. S. (1968). Crime and punishment: An economic approach. Journal of Political Economy, 76, 169-217.

8. Boyle, R., \& Desai, H. (1991). Turnaround strategies for small firms. Journal of Small Business Management, 29, 33-42.

9. Brown, D. (2003). The restaurant manager's handbook: How to set up, operate, and manage a restaurant. New York, NY: Atlantic.

10. Brown, D. (2006). The food service manager's guide to creative cost cutting. Ocala, FL: Atlantic.

11. Buckhoff, T., \& Clifton, J. (2003). Exotic embezzling: investigating off-book fraud schemes. Journal of Financial Crime, 11(3), 249-256.

12. Campbell D., \& Campbell, M. (2006). Guidance for smaller public companies reporting of internal controls. CPA Journal, 906, 22-27.

13. Campbell, D., Campbell, M., \& Adams, G. (2006). Adding significant value with internal controls. CPA Journal, 606, 56.

14. Capella, J.N. (1985). The management conversations. Newbury Park, CA: Sage.

15. Committee of Sponsoring Organizations of the Treadway Commission. (1987). National commission on fraudulent financial reporting. New York, NY: Author.

16. Committee of Sponsoring Organizations of the Treadway Commission. (1992). Internal control-integrated framework Vol. 2. New York, NY: Author.

17. Cook, P. J. (1980). Research in criminal deterrence: Laying the groundwork for the second decade. Crime and Justice: An Annual Review Research, 2, 211-268.

18. Cooper, A., Dunkelberg, W., \& Woo, C. (1989). Survival and failure: A longitudinal study. Journal of Business Ventures, 8(3), 241-253.

19. Cornish, D. B., \& Clark, R. V. (1986). The reasoning criminal: Rational choice perspectives on offending. New York, NY: Springer Verlag.

20. Creswell, J. W. (2003). Research design: Qualitative, quantitative, and mixed method approaches (2 $2^{\text {nd }}$ ed.). Thousand Oaks, CA: Sage.

21. Curtis, M. B., \& Borthick, A. F. (1999). Evaluation of internal control objective narrative. Journal of Information System, 13(1), 63-81.

22. Daft, R. (2007). Organizational theory and design ( $10^{\text {th }}$ ed.). Mason, OH: South Western Cengage Learning.

23. Dillman, D. (2000). Mail and Internet surveys: The tailored design method ( $2^{\text {nd }}$ ed.). New York, NY: John Wiley and Sons.

24. Dow, K., Shea, V., \& Waldrup, B. (2009). Daytona dreams restaurant: linking accounting systems with business valuation. Journal of Information Systems, 23(1), 119-136.

25. Downes, D., \& Rock, P. (2003). Understanding deviance. New York, NY: Oxford University Press.

26. Doyle, J., Ge, W., \& McVay, S. (2005). Accruals quality and internal control over financial reporting. Accounting Review, 82(5), 1141-1170.

27. Doyle, J., Ge, W., \& McVay, S. (2006). Determinant of weaknesses in internal control over financial reporting. Journal of Accounting and Economics, 44, 193-223.

28. Eldridge, S. W., \& Kealey, B. T. (2005). SOX costs: Auditor attestation under section 404. Working paper. University of Nebraska at Omaha.

29. English, W. (1996). Restaurant attrition: a longitudinal analysis of restaurant failures. Journal of Contemporary Hospitality Management, 8(2), 17.

30. Franco, G. D., Guan, Y., \& Lu. (2005). The wealth change and redistribution effects of Sarbanes-Oxley internal control disclosures. Working paper. University of Toronto

31. Frezatti, F., Braga de Aguiar, A., \& Rezende, A. (2006). Relationship between management accounting attributes and user satisfaction. Journal of Accounting Business and Management, 13, 1-24.

32. Ge, W., \& McVay, S. (2005). The disclosure of material weaknesses in internal control after the SarbanesOxley Act. Accounting Horizons, 19(3), 137-158.

33. Grady, P. (1957). The broader concept of internal control. Journal of Accountancy, 18(3), 228-234. 
34. Jackson, M. P. (2006). Sarbanes-Oxley for small business leveraging compliance for maximum advantage. Hoboken, NJ: John Wiley \& Sons.

35. Janvrin, D. J. (2003). St. Patrick Company: Using roleplay to examine internal control and fraud detection concepts. Journal of Information Systems, 17(2), 17-39.

36. Jensen, M. C. (1993). The modern industrial revolution, exit and the failure of internal control systems. Journal of Finance, 48(3), 831-880.

37. Kiger, J. E., \& Rose, A. M. (2004). Internal control evaluation of a restaurant: A teaching case. Issues in Accounting Education, 19(2), 229-237.

38. Kieso, D. E., Weygandt, J. J., \& Warfield, T. D. (2005). Intermediate accounting. New York, NY: John Wiley \& Sons.

39. Kistler, D. (2008). Examining the Protestant church's financial environment, internal controls, \& financial integrity. Doctoral dissertation, Northcentral University, Minneapolis, MN.

40. Kotschevar, L., \& Withrow, D. (2008). Management by menu $\left(4^{\text {th }}\right.$ ed.). Hoboken NJ: John Wiley \& Sons.

41. Lavrakas, P.J. (1993). Telephone survey methods: Sampling, selection, and supervision, $2^{\text {nd }}$ ed. Newbury Park, CA: Sage.

42. Lee, R. (2006). The everything guide to starting and running a restaurant. Avon, MA: F+W.

43. Liska, A. E., \& Messner, S. F. (1999). Perspectives on crime and deviance. Upper Saddle River, NJ: Prentice Hall.

44. Maingot, A. P. (1994). Confronting corruption in the hemisphere: A sociological perspective. Journal of Interamerican Studies \& World Affairs, 94(3), 49-75.

45. Marchetti, M. A. (2005). Beyond Sarbanes-Oxley compliance effective enterprise risk management. Hoboken, NJ: John Wiley \& Sons.

46. McQueen, J. (1989). Causes and lessons of business failure. Journal of Small Business Management, 39, 228-239.

47. McTavish, D., \& Loether, H. (1999). Social research. New York, NY: Addison-Wesley.

48. National Restaurant Association. (2008). Restaurant performance index. Washington, DC: Author.

49. National Restaurant Association Educational Foundation. (2007). Controlling foodservices costs. Upper Saddle River NJ: Pearson Prentice Hall.

50. Nearon, H. B. (2005). Information technology security engagement an evolving specialty. CPA Journal, $77,10$.

51. Needles, B., Powers, M., \& Crosson, S. (2005). Principles of accounting. Boston, MA: Houghton Mifflin.

52. New York State Restaurant Association of Long Island. (2009). Farmingdale, NY: Author.

53. O'Connor, N. G., Vera, S. V., \& Chan, F. (2007). Performance consequences of the Fit between management accounting and control systems and the environment: evidence from publicly listed Chinese firms. Journal of Financial Economics, 64, 705-716.

54. Parsa, H., Self, J., Njite, D., \& King, T. (2005). Why restaurants fail. Cornell Hotel and Restaurant Administration Quarterly, 43(3), 304-322.

55. Pickett, S., \& Pickett, J. (2005). Auditing for managers: The ultimate risk management tool. Chichester, West Sussex, England: John Wiley \& Sons.

56. Public Company Accounting Oversight Board. (2004). Auditing standards on auditing documentation. Washington, DC: Author.

57. Quall, C. J. (2004). Implementing section 404 a practical approach to the Sarbanes-Oxley Act. CPA Journal, 804, 52.

58. Rubin, P. H. (1978). The economics of crime. Atlantic Economic Review, 28, 38-43.

59. Samson, W. D., Flesher, D. L., \& Previs, G. J. (2006). Corporate governance and external and internal controls: the case of the Baltimore and Ohio Railroad, circa 1831. Issues in Accounting Education, 21(1), 45-62.

60. Sanders, E. E., Hill, H. T., \& Faria, J. D. (2008). Understanding foodservice cost control third edition. Upper Saddle River, NJ: Pearson Education.

61. Simmon, H. A. (1947). Administrative behavior. New York, NY: Macmillan

62. Simmons, M. R. (1997). COSO-based auditing. Internal Auditor, 3, 68-73.

63. Singleton, A. R., \& Straits, C. B. (2005). Approaches to social Research ( $4^{\text {th }}$ ed.). Oxford, England: University Press. 
64. U.S. Census Bureau. (2008). U.S. Census bureau Population statistics. Retrieved from http://www.census.gov/compendia/statab/cats/population.html

65. Whittington, R. O., \& Delaney, R. D. (2009). Wiley CPA exam review (36 ${ }^{\text {th }}$ ed.). Hoboken, NJ: John Wiley $\&$ Sons. 


\section{$\underline{\text { NOTES }}$}

